\title{
INFLUENCE OF THE USE OF COVERAGE PLANTS AND THE BIOACTIVATOR IN THE PHYSICAL-BIOLOGICAL CHARACTERISTICS OF SOIL CULTIVATED WITH COFFEE
}

\author{
Kleso Silva Franco Junior ${ }^{1}$, Ligiane Aparecida Florentino², Marcio de Souza Dias ${ }^{3}$, \\ Thais Cristina Franco ${ }^{4}$
}

(Received: February 08, 2019; accepted: March 18, 2019)

\begin{abstract}
One of the alternatives to increase productivity and without harming the environment is the use of green cover associated with soil bioactivators. However, there are still incipient studies reporting the association influence of these two

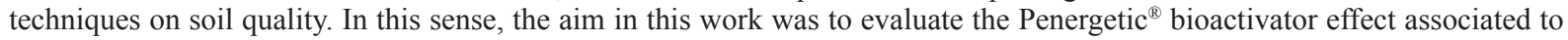
different cover plants on the physical and biological characteristics of the soil cultivated with coffee tree. The experiment was carried out in a coffee field with Catuai Vermelho cultivar IAC 144, in a randomized block design in a factorial scheme 4 x 2 , consisting of control (without plant cover); oats (Avena strigosa) + forage turnip (Raphanus sativus); oats (Avena strigosa) + forage turnip (Raphanus sativus L) + lupine (Lupinus albus) + rye (Secale cereale) + vetch (Vicia sativa) (OFLRV); Brachiaria brizantha (Urochloa brizantha), associated or not with the Penergetic ${ }^{\circledR}$ bioactivator use. The experiment was conducted for 6 months and after that period physical and biological soil characteristics were analyzed. The data were submitted to variance analysis and the means of treatment were grouped by the Scott-Knott test at 5\% probability. The treatments containing cover plants had lower temperature and greater water retention. The bioactivator use reduced the nematodes population from the Meloidogyne genus and when associated to the cover plants showed increased the density of diazotrophic bacteria and solubilizers of phosphorus and potassium.
\end{abstract}

Index terms: Coffee cultivation, Penergetic ${ }^{\circledR}$, Soil microbiota, Sustainable management.

\section{INFLUENCIA DA UTILIZAÇÃO DE PLANTAS DE COBERTURA E BIOATIVADOR NAS CARACTERÍSTICAS FISICO-BIOLÓGICAS DO SOLO CULTIVADO COM CAFÉ}

\begin{abstract}
RESUMO: Uma das alternativas visando aumentar a produtividade e sem agredir o meio ambiente consiste no uso de cobertura verde associada aos bioativadores de solo. No entanto, ainda são incipientes os estudos relatando a influência da associação destas duas técnicas na qualidade do solo. Nesse sentido, o objetivo deste trabalho foi avaliar o efeito do bioativador Penergetic ${ }^{\circledR}$ associado a diferentes plantas de cobertura sobre as características físicas e biológicas do solo cultivado com cafeeiro. O experimento foi instalado em gleba de café contendo a cultivar Catuaí Vermelho IAC 144, em delineamento de blocos casualizados em esquema fatorial 4 × 2 , sendo constituído por: controle (sem planta de cobertura); aveia (Avena strigosa) + nabo forrageiro (Raphanus sativus L); aveia (Avena strigosa) + nabo forrageiro (Raphanus sativus ) + tremoço (Lupinus albus) + centeio (Secale cereale) + ervilhaca (Vicia sativa) (OFLRV); Brachiaria brizantha (Urochloa brizantha), associados ou não ao uso do bioativador Penergetic ${ }^{\circledR}$. O experimento foi conduzido por 6 meses e após esse período foram analisadas características físicas e biológicas do solo. Os dados foram submetidos à análise de variância e as médias dos tratamentos foram agrupadas pelo teste de Scott-Knott a 5\% de probabilidade. Os tratamentos contendo plantas de cobertura apresentaram menor temperatura e maior retenção de água. O uso do bioativador reduziu a população de nematoides do gênero Meloidogyne e quando associado às plantas de cobertura apresentou aumento da densidade de bactérias diazotróficas e solubilizadoras de fósforo e potássio.
\end{abstract}

Termos para indexação: Cafeicultura, Penergetic ${ }^{\circledR}$, Microbiota do solo, Manejo sustentável.

\section{INTRODUCTION}

The green manure consists of the rotating or consortium plants use with the economic interest crops, being considered a management technique that promotes improvement of the physical, chemical and biological characteristics of the soil (NUNES et al., 2006; CARVALHO et al., 2012), and is also responsible for reducing environmental pollution promoted by erosion and leaching of fertilizers and pesticides to watercourses (AVANZI et al., 2013). In addition, it provides reduction of the thermal and moisture oscillations, thus ensuring better conditions for the development of plants and soil organisms.

The organic material provided by the practice of green manure provides an increase in the density and diversity of soil microorganisms

${ }^{1}$ Centro Superior de Ensino e Pesquisa de Machado/CESEP - Av. Dr. Athaide Pereira de Souza s/n - 37.750 -000 - Machado - MG kleso.junior@yahoo.com.br

2, 4Universidade José do Rosário Vellano/UNIFENAS - Rod 179 Km 0 - 37132-440 - Alfenas -MG - ligiane.florentino@unifenas.br, thais_cfranco@hotmail.com

${ }^{3}$ Secretaria de Estado de Educação de Minas Gerais - Escola Estadual Diretor Nelson Rodrigues, 681 - 37.136-000 - Serrania - MG marciodesouzadias2013@gmail.com 
(FILSER, 1995; DUDA et al., 2003), since its residues serve as energy source for metabolic activities. These, in turn, play a fundamental role in the decomposition of organic matter and increase the availability of nutrients to the plants (MOREIRA; SIQUEIRA, 2006). Among the groups of soil microorganisms, deserve to be

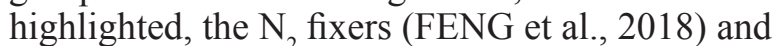
the phosphorus solubilizers (WEI et al., 2018) and potassium (ZHANG; KONG, 2014; MEENA et al., 2015), responsible for increasing the availability of this macronutrients in the soil.

However, in addition to the groups of beneficial organisms, there are pathogens, such as phytonematodes, responsible for large losses in productivity, widely disseminated and difficult to control (CASTRO et al., 2008). Mattei et al. (2017), report on the importance of maintaining the soil organisms population balance, thus favoring the occurrence of ecological interactions, thereby avoiding the population explosion occurrence of the phytonematodes and other pests.

In this way, the green manure use promotes better soil quality, controlling the ecosystem key functions (BATISTA et al., 2013). In addition to this, in the market are found the soil bioactivators, which are constituted by organic substances, humic and fulvic acids, amino acids, algae extract and vitamins that may or may not be associated with micronutrients. These products, according to Castro and Pereira (2008), act in the vegetal development by diverse mechanisms. Külen et al. (2011), declare that these products act in all development stages of the cultivated plants, being able to benefit different crops, such as soybean, corn, wheat and vegetables. According to Assis et al. (2012), the bioactivators reduce the aluminum toxicity and this is due to the formation of organic complexes with calcium and magnesium, which favors their soil movement, thus filling phosphorus adsorption sites and making it available to the plants, besides potentiating the use of fertilizers and contributing to the soil microbiological activity.

The Penergetic ${ }^{\circledR}$ bioactivator has been widely used in Brazil and, among its mechanisms of action, is responsible for favoring the microbial soil activity and, with this, increases the nutrient cycling and, consequently, reduction in the use of chemical fertilizers, providing a better life quality for rural producers and less aggression to the environment (BRITO; DEQUECH; BRITO, 2012). However, despite all these benefits, studies on the joint use the on cover plants of green manure and bioactivators are still incipient.
In this sense, the aim in this work was to evaluate the Penergetic ${ }^{\circledR}$ bioactivator effect associated to different cover plants on the physical and biological characteristics of the soil cultivated with coffee.

\section{MATERIAL AND METHODS}

The experiment was carried out at Farm Boa Esperança, located in the country of Serrania, South of Minas Gerais, during the months from May to December 2016. The experimental area has the following geographical coordinates: Latitude: 21 $1^{\circ} 36^{\prime} 18.29^{\prime \prime}$, Longitude: $46^{\circ} 7^{\prime} 46.29^{\prime \prime} \mathrm{W}$ and Altitude of $982 \mathrm{~m}$. The coffee grounds selected were those cultivated with Catuai Vermelho IAC 144, implanted in 2011, spacing $3.5 \mathrm{~m}$ between rows and $0.7 \mathrm{~m}$ between plants, totaling $4081 \mathrm{pls} /$ ha.

The experimental design was a randomized complete block design in a $4 \times 2$ factorial scheme, with 4 soil cover conditions associated to the use or not of Penergetic ${ }^{\circledR}$ bioactivator and 4 replications, totaling 32 experimental units. The four soil cover conditions were: 1) control, without cover plant; 2) oats (Avena strigosa) + forage turnip (Raphanus sativus L); 3 ) oats (Avena strigosa) + forage turnip (Raphanus sativus L) + lupine (Lupinos albus) + rye (Secale cereale) + vetch (Vicia sativa) (OFLRV); 4) Brachiaria brizantha.

Each experimental unit consisted of 10 coffee plants, being considered for the analysis only the 6 central plants, being the useful area of the parcel of approximately $74 \mathrm{~m}^{2}$ and the experimental area of $0.24 \mathrm{ha}^{-1}$. The planting densities of the cover plants were: Brachiaria brizantha and forage turnip, $10 \mathrm{~kg} \mathrm{ha}^{-1}$, oats $40 \mathrm{~kg}$ $\mathrm{ha}^{-1}$, lupine and rye $20 \mathrm{~kg} \mathrm{ha}^{-1}$ and vetch $15 \mathrm{~kg}^{-}$ ${ }^{1}$. The bioactivator was used in the dosage of 0.6 $\mathrm{kg} \mathrm{ha}^{-1}$. The sowing was done in shallow grooves, using 3 lines in the middle of the coffee streets, distant from each other by $50 \mathrm{~cm}$. For both the seed quantity and the Penergetic ${ }^{\circledR}$ bioactivator to be applied, the manufacturer's recommendations were followed.

The cover plants were kept in the area from May to October, when the mowing was done and these were conserved in the coffee intercropped. The soil temperature was measured on its surface, using an infrared thermometer, at $1 \mathrm{pm}$, weekly, for 32 weeks (may/december), resulting in an average. Two months later, soil samples were taken for moisture analysis, which was determined by the direct (gravimetric) method, which is the most 
used, consisting of sampling the soil and, through weighing, determining its gravimetric moisture, correlating the water mass with the sample solids mass or the volumetric moisture, relating the water volume contained in the sample and its volume (EMBRAPA, 1997).

Soil and root samples, for nematode analysis, were collected under the canopy, where the highest root concentration was found according to the methodology recommended by Salgado, Carneiro and Pinho (2011) and sent to the nematology laboratory of the Federal University of Lavras - UFLA.

The soil samples collected for the microbiological analyzes were carried out with flambé auger to avoid contamination between the treatments. The population density of the bacterial groupswasevaluated by the serialdilution technique using the following culture media: associative diazotrophs - FAM Medium (DÖBEREINER et al., 1995), phosphate solubilizing bacteria - NBRIP Medium (NAUTIYAL et al., 2000) and potassium - Aleksandrov Medium (PARMAR; SINDHU, 2013). In the soil samples collection for the nematode and microbiological analyzes, the auger was flambed after collection in each treatment to avoid contamination, being placed in sterilized containers, transported in a thermal box and taken to the Agricultural Microbiology Laboratory of the José do Rosário Vellano University (UNIFENAS)

The data were submitted to variance analysis and the averages were compared by the Scott-Knott test at 5\% probability using the Sisvar $^{\circledR}$ computer program (FERREIRA, 2014).

\section{RESULTS AND DISCUSSION}

Analyzing the values of the physical parameters, temperature and moisture, it was observed that there was no interaction between soil cover versus bioactivator, only soil cover influenced the values of these parameters (Table 1).

In relation to the temperature, it was verified that the different treatments containing cover plants were similar to each other, presenting smaller values when compared to the control treatment (without soil cover). For moisture, the positive effect of soil cover was also observed, and the treatments containing OFLRV and $B$. brizantha were the ones that presented higher water retention in the soil.

These results agree with those reported by Lima et al. (2017) and Ribeiro et al. (2018), who mention the positive influence of cover plants on the reduction of soil water evaporation and mitigate the temperature, factors that favors the root development with greater absorption of water and nutrients and, consequently, ensuring greater agricultural productivity.

The OFLRV treatment, constituted by cruciferous, grass and leguminous plants, which have different morphological characteristics of the root system may have had a positive influence on the higher water retention. Studies show the importance of grasses, such as the Brachiaria genus in soil quality improvement, with emphasis on maintaining moisture (ANDRIOLI et al., 2008). Prando et al. (2010), relate to higher water retention in soils grown with Brachiaria ruziziensis due to the improvement in the size and numbers of biopores, which facilitates the penetration of water into the soil, in agreement with the results found in this study.

Other studies confirm the importance of soil cover to increase infiltration and moisture maintenance, since they reduce the raindrops impact, disintegrating the soil and, as observed in this study, reduce soil temperature, besides increasing the organic matter contents (CARVALHO et al., 2012; MOREIRA; PAIVA; DINIZ, 2017).

In the soil biological characteristics, in relation to the population density of nematodes, no interaction between soil cover versus bioactivator was observed, and the population of the Meloidogyne genus was only influenced by the bioactivator use (Table 2), while the nematodes density of the Xiphinema genus was affected by the soil cover type (Table 3).

Analyzing Table 2, there is a significant reduction of the nematode population of the Meloidogyne genus by the bioactivator use. According to Assis et al. (2012), bioactivators increase soil microbiological activity, which, according to Elhady et al. (2017) can act in the phytonematodes control. Mattei et al. (2017), report on the bacteria efficiency of the Pasteuria genus, found in soil, in reducing the number of galles formed by Meloidogyne spp.

Considering the importance of the nematodes control for agriculture and studies are still incipient on the effects of the use of soil bioactivators, the results obtained are of great relevance, since the Meloidogyne genus occurs in all the coffee regions of Brazil, mainly in the states of São Paulo, Rio de Janeiro, Paraná, Minas Gerais, Espírito Santo and Bahia, causing damages to the national coffee industry (MATIELLO et al., 2010). 
TABLE 1 - Temperature and soil afther handling the cover plants, moisture and soil in the coffee plantation as a function of the cover plants in dezember 2016.

\begin{tabular}{lcc}
\hline Soil cover & Temperature $\left({ }^{\circ} \mathrm{C}\right)$ & Moisture $(\%)$ \\
\hline Control & $30.88 \mathrm{a}$ & $15.75 \mathrm{c}$ \\
Oats and turnips & $27.99 \mathrm{~b}$ & $21.75 \mathrm{~b}$ \\
OFLRV* & $27.78 \mathrm{~b}$ & $27.00 \mathrm{a}$ \\
Brachiaria brizantha & $27.27 \mathrm{~b}$ & $30.38 \mathrm{a}$
\end{tabular}

Averagets of treatment followed by the same letter, in the column, do not differ by Scott Knott's test at 5\% probability. *Abbreviation of treatment: oat + forage turnip + lupine + rye + vetch.

TABLE 2- Nematodes density of the Meloidogyne genus in soil samples collected in the coffee intercropped grown under different cover plants, after handling the cover plants.

\begin{tabular}{lc}
\hline \multicolumn{1}{c}{ Penergetic $^{\circledR}$} & Meloidogyne density $\left(100 \mathrm{~cm}^{3}\right.$ soil $)$ \\
\hline With & $7.12 \mathrm{~b}$ \\
Without & $12.50 \mathrm{a}$
\end{tabular}

Averagets of treatment followed by the same letter, in the column, do not differ by Scott Knott's test at 5\% probability.

TABLE 3 - Nematodes density of the Xiphinema genus in soil samples collected in the coffee intercropped grown under different cover plants, after handling the cover plants.

\begin{tabular}{|c|c|}
\hline Soil cover & Xiphinema density $\left(100 \mathrm{~cm}^{3}\right.$ soil $)$ \\
\hline Control & $5.75 \mathrm{a}$ \\
\hline Oats and turnips & $2.75 \mathrm{a}$ \\
\hline OFLRV* & $0.00 \mathrm{~b}$ \\
\hline Brachiaria brizantha & $0.25 \mathrm{~b}$ \\
\hline
\end{tabular}

Averagets of treatment followed by the same letter, in the column, do not differ by Scott Knott's test at 5\% probability *Abbreviation of treatment: oat + forage turnip + lupine + rye + vetch.

Table 3 shows the results of the nematode density of the Xiphinema genus, which was influenced by the different types of soil cover.

It is observed that the OFLRV and $B$. brizantha treatment significantly reduced the nematode population, presenting lower results than the other treatments. Although this nematodes genus is not a problem in the coffee crop, this confirms the importance of cover plants, which, by promoting diversity in the population of predatory fungi, plays an important role in reducing population nematodes density, of different genera, that cause damage in many crops (INOMOTO; ASMUS, 2014).
In the microbiological parameters, it was observed that there was interaction between soil cover versus bioactivator, and, in general, the presence of cover plants associated to the bioactivator use increased the density of the bacteria groups, evidencing the synergistic effect between cover plants and bioactivators.

Averagets of treatment followed by the same letter, in the column, do not differ by Scott Knott's test at $5 \%$ probability. *Abbreviation of treatment: oat + forage turnip + lupine + rye + vetch.

In the bioactivator and cover plants presence a largest population of diazotrophic bacteria was obtained. 
TABLE 4 - Average of log of UFC.mL ${ }^{-1}$ for the diazotrophic bacteria groups, potassium and phosphorus solubilizers isolated from soil samples collected in the coffee intercropped grown with different cover plants with or without the Penergetic ${ }^{\circledR}$ bioactivator, after handling the cover plants.

\begin{tabular}{crrrrrr}
\hline & \multicolumn{7}{c}{ Bioactivator } \\
\cline { 2 - 7 } Soil cover & \multicolumn{7}{c}{ With } & Without & With & Without & With & Without \\
\cline { 2 - 7 } & \multicolumn{2}{c}{ Diazotrophic } & \multicolumn{2}{c}{$\begin{array}{c}\text { Potassium } \\
\text { solubilizers }\end{array}$} & $\begin{array}{c}\text { Phosphorus } \\
\text { solubilizers }\end{array}$ \\
\cline { 2 - 7 } Control & $4.64 \mathrm{Ba}$ & $3.74 \mathrm{Aa}$ & $3.09 \mathrm{Ca}$ & $3.23 \mathrm{Ba}$ & $3.07 \mathrm{Ba}$ & $3.35 \mathrm{Ba}$ \\
OFLRV* & $5.74 \mathrm{Aa}$ & $4.09 \mathrm{Ab}$ & $7.30 \mathrm{Aa}$ & $5.37 \mathrm{Ab}$ & $6.44 \mathrm{Aa}$ & $3.39 \mathrm{Bb}$ \\
$\begin{array}{c}\text { Oats and Turnip } \\
\text { Brachiaria } \\
\text { Brizantha }\end{array}$ & $5.75 \mathrm{Aa}$ & $3.80 \mathrm{Ab}$ & $3.24 \mathrm{Ca}$ & $2.96 \mathrm{Ba}$ & $3.71 \mathrm{Ba}$ & $4.22 \mathrm{Ba}$ \\
\hline
\end{tabular}

Averagets of treatment followed by the same letter, in the column, do not differ by Scott Knott's test at $5 \%$ probability. *Abbreviation of treatment: oat + forage turnip + lupine + rye + vetch.

On the other hand, when the bioactivator was not used, no statistical difference was observed in the density of these bacteria.

For the potassium solubilizers group, the OFLRV treatment associated to the bioactivator provided a higher population density, followed by the soil cover containing $B$. brizantha. In the phosphorus solubilizers, the OFLRV treatment with the bioactivator use was also highlighted, which was similar to that of $B$. brizantha.

The cover plants influence, as well as the rhizospheric effect on the soil microbial population is well reported by Moreira and Siqueira (2006), however, studies are needed aiming to identify possible soil bioactivators action mechanisms associated with cover plants on the soil microorganisms. In this sense, the results obtained in this study are of great relevance for research and for coffee cultivation in general, since there is now a need to identify alternative sources of nutrients to reduce dependence on fertilizer imports by Brazil and that are sustainable, thus ensuring the products competitiveness on the external market.

\section{CONCLUSIONS}

The use of cover plants positively influenced soil temperature and moisture in the coffee intercropped. The use of the Penergetic ${ }^{\circledR}$ bioactivator reduced the nematode population of the Meloidogyne genus and when associated with the use of cover plants, increased the population density of diazotrophic and solubilizers bacteria of phosphorus and potassium.

\section{ACKNOWLEDGEMENT}

The authors thank José do Rosário Vellano University (UNIFENAS); to the National Council for Scientific and Technological Development $(\mathrm{CNPq})$ for scientific initiation fellowships; the Scientific Directorate of the Foundation for Research Support of the State of Minas Gerais (Fapemig) to the Coordination of Improvement of Higher Education Personnel - Brazil (CAPES/ Finance Code 001) for the doctorate scholarship; to the Nucleus of Higher Education and Research of Machado - MG (CESEP); the Technical Assistance and Rural Extension Company of the State of Minas Gerais (EMATER - MG); Pirai Seeds; Farm Boa Esperança and Renovagro.

\section{REFERENCES}

ANDRIOLI, Itamar et al. Produção de milho em plantio direto com adubação nitrogenada e cobertura do solo na pré-safra. Revista Brasileira Ciência do Solo. Viçosa, v. 32, n. 4, p. 1691-1698, 2008.

ASSIS, R.T.; TOMAZ, H.V.Q. O cerrado hoje e o seu potencial de produção agrícola. In: SILVA, J.C.; SILVA, A.A.S. Sustentabilidade Produtiva do Cerrado. Uberlândia: Composer, 2012. p. 204-219.

AVANZI, J. C. et al. Spatial distribution of water erosion risk in a watershed with eucalyptus and Atlantic Forest. Ciência e Agrotecnologia, v. 37, n. 5, p. 427-34, setout. 2013. 
BATISTA, M.A.V.; BEZERRANETO, F.;AMBRÓSIO, M.M.Q.; GUIMARÃES, L.M.S.; SARAIVA, J.P.B. E SILVA, M.L. Atributos microbiológicos do solo e produtividade de rabanete influenciados pelo uso de espécies espontâneas. Revista Horticultura Brasileira. vol. 31, n. 4, p.587-594, 2013.

BRITO, O. R.; DEQUECH, F. K.; BRITO, R. M. Use of penergetic procucts $\mathrm{P}$ and $\mathrm{K}$ in snap bean production. Annual report of the bean improvement cooperative. v. 55, p. 279-280, 2012.

CASTRO, J. M. da C. e; CAMPOS, V. P.; POZZA, E. A.; NAVES, R. de L.; ANDRADE JÚNIOR, W. C.; DUTRA, M.R.; COIMBRA, J.L.; MAXIMINIANO, C.; SILVA, J. R. C.. Levantamento de fitonematóides em cafezais do sul de Minas Gerais. Nematologia Brasileira, Piracicaba,v. 32, n. 1, p. 56- 64,mar. 2008.

CASTRO, P.R.R.; PEREIRA, M. A. Bioativadores na agricultura. In: GAZZONI, D. L. (Ed.). Tiametoxam: uma revolução na agricultura brasileira. Petrópolis: Vozes, p. 115-122. 2008

CARVALHO, M. A. R.; MIRANDA, J. H.; DUARTE, S. N; CARVALHO, L. C. C. Escoamento superficial na interação: cobertura vegetal e práticas de controle de erosão. Engenharia Agrícola, v. 32, n. 6, p. 1116$1125,2012$.

DÖBEREINER, J.; BALDANI, V. L. D.: BALDANI, J. I. Como isolar e identificar bactérias diazotróficas de plantas não-leguminosas, Brasília: Embrapa-SPI, $199560 \mathrm{p}$.

DUDA, G.P.; GUERRA, J.G.M.; MONTEIRO, M.T.; DE-POLLI, H.; TEIXEIRA, M.G. Perennial herbaceous legumes as live soil mulches and their effects on $\mathrm{C}, \mathrm{N}$ and $\mathrm{P}$ of the microbial biomass. Scientia Agricola, v.60, p.139-147, 2003.

ELHADY, A.; GINÉ, A.; TOPALOVIC, O.; JACQUIOD, S.; SØRENSEN, S. J.; SORRIBAS, F. J. and HEUER, H. Microbiomes associated with infective stages of root-knot and lesion nematodes in soil. PloS one, v.12, n.5, 2017.

EMBRAPA. Manual de métodos de análise de solo. 2. ed. Rio de Janeiro, 1997. 212p. (Documentos, 1).

FENG, M.; ADAMS, J. A.; FAN, K.; SHI, Y.; SUN, R.; WANG, D.; GUO, X.. CHU H. Long-term fertilization influences community assembly processes of soil diazotrophs. Soil Biology and Biochemistry, V.126, p. 151-158, 2018.
FERREIRA,D.F. Sisvar:umguiadosseusprocedimentos de comparações múltiplas Bootstrap. Ciência e Agrotecnologia, v. 38, n. 2. p. 109-112, 2014.

FILSER, J. The effect of green manure on the distribution of collembola in a permanent row crop. Biology and Fertility of Soils, Berlin, v.19, n.4, p.3038,1995 .

INOMOTO, M. M.; ASMUS, G. L. Adubos verdes das famílias fabaceae e mimosaceae para o controle de fitonematoides. In: LIMA FILHO, O.F. et al. Adubação verde e plantas de cobertura no Brasil. Brasília: Embrapa, 2014. cap.12, p.441-479.

KÜLEN, O. et al. Gibberellic acid and ethephon alter potato minituber bud dormancy and improve seed tuber yield. American Journal of Potato Research, v. 88, n. 2, p. 167-174, abril 2011.

LIMA, B. V.; SOUZA, G. G.; OLIVEIRA, T. O. P.; OLIVEIRA, J. A. G. EFEITOS DA ADUBAÇÃO VERDE NOS ATRIBUTOS DO SOLO. Revista Conexão Eletrônica - Três Lagoas, MS - V.14, n.1, p.515-523, 2017.

MATEI, D.; HENKEMEIER, P.; HELING, A. L.; LORENZETTI, E.; KUHN, O. J.; STANGARLIN, J. R. Produtos fitossanitários biológicos disponíveis para agricultura e perspectivas de novos produtos. In: ZAMBOM, M. A.; KUHN, O. J.; SILVA, N. L. S.; STANGARLIN, J. R.; NUNES, R. V.; FULBER, V. M.; EYNG, C.(Org.) Ciências agrárias: ética do cuidado, legislação e tecnologia na agropecuária / C569. Marechal Cândido Rondon, 2017. 228 p.

MATIELLO, J. B. et al. Cultura de café no Brasil: novo manual de recomendações. Rio de Janeiro e Varginha: MAPA/PROCAFÉ, 2010. 542 p.

MEENA, V. S. et al. Potassium solubilizing rhizobacteria (KSR): Isolation, identification, and K-release dynamics from waste mica. Ecological Engineering, v. 81, p. 340-347, aug. 2015.

MOREIRA, F.M.S. \& SIQUEIRA, J.O. Microbiologia e bioquímica do solo. 2.ed. Lavras, Universidade Federal de Lavras, 2006. 729p.

MOREIRA, C. F.; PAIVA, A. O.; DINIZ, C. V. C. Clima e água para uma cafeicultura. Machado: Associação de Cafeicultura Orgânica do Brasil, 2017. 44 p. il. 
NAUTIYAL, C. S. et al. Stress induced phosphate solubilization in bacteria isolated from alkaline soils. FEMS Microbiol. Lett., v. 182, n. 2, p. 291-296, 2000.

NUNES, U.R.; ANDRADE JÚNIOR, V.C.; SILVA, E.B. SANTOS, N.F.; COSTA, H.A.O.; FERREIRA, C.A. Produção de palhada de plantas de cobertura e produtividade do feijão em plantio direto. Pesquisa Agropecuária Brasileira, v.41, n.6, p.943-948, jun. 2006.

PARMAR, P.; SINDHU, S.S. Potassium solubilization by rhizosphere bacteria: influence of nutritional and environmental conditions. International of Journal Microbiology Research, v.3, n. 1, p. 25-31, out. 2013.

PRANDO, M. B.; OLIBONE, D.; OLIBONE, A. P. E.; ROSOLEM, C. A. Infiltração de água no solo sob escarificação e rotação de culturas. Revista Brasileira de Ciência do Solo. vol.34 no.3 Viçosa May/June 2010. P. 693-700.
RIBEIRO, H.A. B. R.; DINIZ, E. R.; SOUZA JÚNIOR, J. B.; MOURO, G. F.; MARTINKOSKI, L. Qualidade do solo sobre manejo com palha e adubação verde em cobertura. Cadernos de Agroecologia - ISSN 22367934 - Anais do VI CLAA, X CBA e V SEMDF - Vol. 13, N 1, Jul. 2018.

SALGADO, S.M. de L. , CARNEIRO, R.M. D.G.: PINHO, R. S. C de: Aspectos técnicos dos nematoides parasitas do cafeeiro. - Belo Horizonte: EPAMIG, 2011. p 29 -33.

WEI, Y.; ZHAO, Y.; SHI, M.; CAO, Z.; LU, Q.; YANG, T.; FAN, Y.; WEI, Z. Effect of organic acids production and bacterial community on the possible mechanism of phosphorus solubilization during composting with enriched phosphate-solubilizing bacteria inoculation. Bioresource Technology, Volume 247, January 2018, Pages 190-199.

ZHANG, C.; KONG F. Isolation and identification of potassium-solubilizing bacteria from tobacco rhizospheric soil and their effect on tobacco plants. Applied Soil Ecology, v. 82, p. 18-25, oct. 2014. 